\title{
Financial Literacy: An Overview of Practice, Research, and Policy
}

Sandra Braunstein and Carolyn Welch, of the Board's Division of Consumer and Community Affairs, prepared this article.

In recent years, financial literacy has gained the attention of a wide range of major banking companies, government agencies, grass-roots consumer and community interest groups, and other organizations. Interested groups, including policymakers, are concerned that consumers lack a working knowledge of financial concepts and do not have the tools they need to make decisions most advantageous to their economic well-being. Such financial literacy deficiencies can affect an individual's or family's day-to-day money management and ability to save for long-term goals such as buying a home, seeking higher education, or financing retirement. Ineffective money management can also result in behaviors that make consumers vulnerable to severe financial crises.

From a broader perspective, market operations and competitive forces are compromised when consumers do not have the skills to manage their finances effectively. Informed participants help create a more competitive, more efficient market. As knowledgeable consumers demand products that meet their short- and long-term financial needs, providers compete to create products having the characteristics that best respond to those demands.

As concern about financial literacy has increased, so too have the number and variety of financial literacy training programs and program providerssome offering comprehensive information on savings, credit, and similar topics for a broad audience and others tailored to a specific group, such as youth or military personnel, or focused on a specific goal, such as home ownership or savings.

The findings of studies of the effectiveness of financial literacy training have been mixed. Although some programs, particularly those having discrete objectives, have succeeded in improving certain aspects of consumers' personal financial management-such as maintaining a mortgage, increasing savings, or participating in employersponsored benefit plans - improved financial behavior does not necessarily follow from increased finan- cial information. The timing and format of training, as well as human traits such as aversion to change, play a role in whether programs will effect positive change that contributes to households' long-term financial well-being. Accounting for all the variables associated with financial literacy training-when, how, and where it is delivered, who is trained, and what information is presented-poses a great challenge for program developers. Given the resources now devoted to financial literacy training, this is an opportune time to evaluate the research, identify best practices, and consider public policy options that would further the goal of creating more financially savvy consumers.

\section{CHANGES PROMPTING INCREASED ATTENTION TO FINANCIAL LITERACY}

Numerous factors have led to a complex, specialized financial services marketplace that requires consumers to be actively engaged if they are to manage their finances effectively. The forces of technology and market innovation, driven by increased competition, have resulted in a sophisticated industry in which consumers are offered a broad spectrum of services by a wide array of providers. Compelling consumer issues, such as the very visible issue of predatory lending, high levels of consumer debt, and low saving rates, have also added to the sense of urgency surrounding financial literacy. Other important demographic and market trends contributing to concerns include increased diversity of the population, resulting in households that may face language, cultural, or other barriers to establishing a banking relationship; expanded access to credit for younger populations; and increased employee responsibility for directing their own investments in employer-sponsored retirement and pension plans.

\section{Technological Changes and Market Innovation}

Over the past decade, technological advances have transformed nearly every aspect of the marketing, 
delivery, and processing of financial products and services. The expansion of the Internet as a means of communicating and delivering services has also enabled financial services providers to market financial products and serve customers more efficiently. Communication and delivery innovations increase the amount of information available to consumers and allow them to shop for and choose from a wide array of products and services without geographic limitation. To benefit from the innovations, however, consumers need a base level of financial knowledge, so that they can identify and access pertinent information as well as evaluate the credibility of the source of the information.

Technological advances have also increased the capacity for targeted marketing to consumers, with robust databases of consumer information making it possible to match household characteristics and preferences with product offerings. This application of technology can promote competition and improve customer service. However, its misuse can increase consumer vulnerability to unscrupulous lenders. Questionable marketing and sales tactics may induce consumers to acquire products that they do not need or that are inappropriate for their circumstances.

In addition to broadening the application of databases in marketing, technology has enabled the use of databases in loan underwriting. Using statistical modeling, sophisticated computer programs produce a numerically based risk profile of consumers to establish a range of acceptable risk and to develop guidelines for pricing credit. While credit-scoring technology has increased loan production and decreased creditor costs, it has also diminished lender-customer interaction. With the lack of personal involvement, consumers, particularly those unfamiliar with banking and credit systems, have limited means for obtaining insight on the elements in their financial profile that affect decisionmaking and guidance on the course of action necessary to improve their creditworthiness.

Market innovation and competition within the financial services industry can also be seen in the increase in the variety of products offered by depository institutions. For example, basic deposit and credit products have multiplied and become highly specialized. In addition, there has been a proliferation of nonbank providers of financial services, such as payday lenders and check cashers. (The number of check-cashing centers has doubled over the past five years, according to Financial Service Centers of America, Inc.) These developments have given consumers more options and greater flexibility in creating financial arrangements that best suit their needs.
However, consumers may have difficulty assessing the options, and a misguided choice can result in higher costs due to monthly fees, overdrafts, or excessive transactions.

Market innovation has also prompted deregulation of the banking industry. As competition from nonbanking institutions has increased over time, banks have devised ways to offer products to customers outside the bank-regulated structure. In response to these market realities, legislation was passed in 1999 to eliminate the regulatory barriers that had prohibited banks from engaging in the sale of securities and insurance, enabling bank-owned financial holding companies to become one-stop financial services providers. This legislation (the Gramm-Leach-Bliley Act), recognizing the activities already occurring within the marketplace, facilitated financial modernization and promoted a more efficient financial services industry. However, the expansion of financial products offered by banking organizations, for example, securities and insurance, requires consumers to become more aware of the distinction between these products and to recognize that they do not convey the same consumer protections and rights as traditional banking products.

\section{Rise in Questionable Mortgage Lending Practices}

An increase in anecdotal reports of unfair and deceptive home equity lending practices in the late 1990s raised concerns about the scope and impact of unscrupulous credit arrangements, commonly referred to as predatory lending. Investigations and public hearings by federal, state, and local government agencies to identify possibly unethical or predatory mortgage lending practices revealed that in many cases the terms of such contracts are not technically illegal but rather are inappropriate for and disadvantageous to consumers. An example is a loan structured with relatively small fixed payments in the early years but a large "balloon" payment at the end of the loan term. Such a structure recognizes that a younger borrower's future earning potential is generally greater than his or her current income and assumes that the borrower will be able to refinance at the end of the loan term. While the arrangement makes mortgage payments more affordable for some borrowers, it can be devastating to those living on fixed incomes.

Efforts by government agencies to better understand predatory lending have generally found that the distortion or inappropriate use of credit provisions, coupled with the inherent complexity of mortgage 
lending, sometimes results in borrowers becoming entangled in a financially devastating credit quagmire. Borrowers who are unfamiliar with credit transactions and unaware of the full implications of the loan terms may be vulnerable to unethical lenders' sales strategies. Although regulatory protections and legal remedies are important, consumer education is seen as an essential element for combating and preventing predatory lending. ${ }^{\text {? }}$

\section{Changes in Personal Finances}

Other factors prompting increased attention to financial literacy include the rise in consumer debt levels, the decline in already-low personal saving rates, and the increase in non-business bankruptcy filings. Although the rate of expansion of consumer credit in 2001 was well below that in $2000(6.5$ percent compared with 10.25 percent), outstanding household debt increased an estimated 8.75 percent in 2001, a rate about 1 percentage point faster than the average growth over the preceding two years. Household borrowing outstripped the growth of disposable personal income in that year, with the household debtservice burden - an estimate of minimum scheduled

1. In 1999 and 2000 , a variety of efforts were undertaken by federal, state, and local agencies to gain insight into abusive lending practices. The Federal Reserve hosted a series of public hearings to obtain comment on proposed revisions to the regulation implementing the Home Ownership Equity Protection Act, a statute enacted to stem unscrupulous lending by increasing disclosure requirements and consumer protections for high-eost loans (www.federalreserve.gov/ events/publichearings/default.htm). A joint task force of the Department of Housing and Urban Development and the Department of the Treasury released a report of findings and policy recommendations regarding predatory lending (www.huduser.org/publications/hsgfin/ curbing.html). In both cases, financial education was recommended as a means of helping borrowers better understand the basics of mortgage credit. payments on mortgage and consumer debt as a share of disposable income-reaching near-record levels. Meanwhile, although the personal saving rate rose on average in 2001, it registered below 1 percent at year-end. ${ }^{2}$ In addition, a record number of nonbusiness bankruptcies, approximately 1.5 million, were filed in 2001, an increase of more than 19 percent from 2000. ${ }^{3}$ Together, these data suggest that some consumers may be vulnerable to a financial crisis in the event of an economic shock such as the loss of employment or a protracted illness.

\section{Changes in Demographics}

Data from the 2000 census confirm that the U.S. population has become considerably more diverse and that foreign-born households represent an important consumer market force. Many in these groups, as is common among underserved populations, may be unfamiliar with U.S. financial practices and (or) lack access to mainstream financial systems. Language, educational, and cultural barriers can discourage some populations from establishing a banking relationship to acquire financial services. Instead, they may use alternative providers to conduct basic transactions such as cashing checks, obtaining loans, or wiring funds. Although using alternative providers may be convenient or comfortable, a report by the Fannie Mae Foundation asserts that they generally charge higher per-transaction fees (table 1). Financial literacy programs promote participation in the banking system to enable consumers to gain access to a

2. Statistics on debt and savings are from "Monetary Policy Report to the Congress," Federal Reserve Bulletin, vol. 88 (March 2002), pp. 141-72.

3. American Bankruptcy Institute, "U.S. Bankruptcy Filings 19802001" (www.abiworld.org/stats/1980annual.html).

1. Estimated fees for financial services charged by nonbank providers, 2002

\begin{tabular}{|c|c|c|c|c|}
\hline Service & $\begin{array}{l}\text { Rate per transaction } \\
\text { (percent) }\end{array}$ & $\begin{array}{c}\text { Number of transactions } \\
\text { (millions) }\end{array}$ & $\begin{array}{l}\text { Gross revenue } \\
\text { (billions of dollars) }\end{array}$ & $\begin{array}{l}\text { Total fee revenue } \\
\text { (billions of dollars) }\end{array}$ \\
\hline Check cashing .... & $\begin{array}{l}\text { Payroll and government, } 2-3 \\
\text { Personal, can exceed } 15\end{array}$ & 180 & 60 & 1.5 \\
\hline Payday loans $\ldots \ldots \ldots \ldots \ldots$ & $\begin{array}{l}15-17 \text { per two weeks } \\
400 \mathrm{APR}\end{array}$ & $55-69$ & $10-13.8$ & $1.6-2.2$ \\
\hline Pawnshops ........ & $\begin{array}{l}1.5-25 \text { per month } \\
30-300 \mathrm{APR}\end{array}$ & 42 & 3.3 & n.a. \\
\hline Rent-to-own ........ & 2 or 3 times retail & 3 & 4.7 & 2.35 \\
\hline Auto title lenders $\quad \ldots \ldots \ldots \ldots \ldots$ & $\begin{array}{l}1.5-25 \text { per month } \\
30-300 \mathrm{APR}\end{array}$ & n.a. & n.a. & \\
\hline Total & . & 280 & 78 & 5.45 \\
\hline
\end{tabular}


full complement of services, with the possible result of significant savings in transaction fees. ${ }^{4}$ An additional benefit of engagement with the banking system is suggested by research indicating that 51 percent of households that have a banking relationship save regularly, compared with 14 percent of households that do not. 5

\section{Increase in Consumen Responsibilities}

Consumer responsibilities for credit and investment management have increased in recent years. For example, greater competition and more-flexible underwriting standards have increased younger populations' access to credit. It is not uncommon for college students, even those lacking a job or other source of income, to obtain a credit card. In a 2001 study by the U.S. General Accounting Office, more than 33 percent of surveyed students indicated that they had a credit card before they entered college, and another 46 percent had acquired a card in their freshman year of college. ${ }^{6}$ Evidence that younger populations are having difficulty managing debt is revealed in statistics showing a 51 percent increase in bankruptcy filings by debtors under the age of twenty-five between 1991 and 1999.?

Consumers' responsibilities for their retirement investments have also grown. Employers are increasingly offering defined-contribution plans, for which the employee directs the investment, rather than defined-benefit plans, for which the employer makes the investment decisions on behalf of its employees. In 1980, 70 percent of pension plans were structured as defined-contribution plans; by 1997, the proportion had risen to 92 percent. ${ }^{8}$ Moreover, surveys indicate that as many as 30 percent of eligible employees do not participate in employer retirement plans. ${ }^{9}$ Financial training can help employees devise

4. James H. Carr and Jenny Schuetz, "Financial Services in Distressed Communities: Framing the Issue, Finding Solutions" (Fannie Mae Foundation, August 2001) (www.fanniemaefoundation.org/ programs/papers.shtml).

5. Constance R. Dunham, "The Role of Banks and Nonbanks in Serving Low- and Moderate Income Communities,'” in Jackson L. Blanton, Alicia Williams, and Sherrie L. W. Rhine, eds., Changing Financial Markets and Community Development: Proceedings of a Federal Reserve System Community Affairs Research Conference (April 2001), pp. 31-58 (www.chicagofed.org/cedric/2001/ sessionone.cfm).

6. U.S. General Accounting Office, "Consumer Finance: College Students and Credit Cards," Report GAO-01-773 (GAO, June 2001). 7. Ibid.

8. U.S. Department of Labor, "The National Summit on Retirement Savings: Agenda Background Materials" (prepared by C. Conte), 1998.

9. Mark Dolliver, "Just Blame It on Ignorance, if Not on Improvidence," Adweek, vol. 42 (March 2001). an investment strategy that ensures their retirement security - first by recognizing the advantage of contributing to employer-sponsored savings plans and then by understanding their future needs, goals, and appetite for risk.

\section{PROVIDERS AND FOCUS OF FINANCIAL LITERACY TRAINING}

Efforts to improve the quality and increase the amount of the financial information provided to consumers have been in place for many years. In a broad sense, the disclosure of key terms and costs of lending and deposit transactions dictated by federal consumer protection laws constitute a financial education tool, as they are intended to enable consumers to compare the same type of information across products. Although the utility of disclosure documents has been debated, disclosures are generally viewed as an important mechanism for communicating important information to consumers.

What is new is the proliferation of programs. A study commissioned by Fannie Mae found that twothirds of the ninety financial literacy programs that it examined were begun in the 1990s and that threefourths of those were initiated in the late 1990s or 2000.10

The providers of financial literacy programs are a diverse group that includes employers, the military, state cooperative extension services, community colleges, faith-based groups, and community-based organizations. Commercial banks are also important providers of financial literacy education. All but two of the forty-eight retail banks responding to a recent survey by the Consumer Bankers Association reported contributing to financial literacy efforts in some way. ${ }^{1 "}$ Many banks consider their engagement in this area a way to expand their customer base and promote goodwill, and such activities are often given favorable consideration in examinations for compliance with the Community Reinvestment Act.

The content and audience of financial literacy programs also vary considerably. Some programs, such as the Federal Deposit Insurance Corporation's "Money Smart" curriculum, offer comprehensive

10. Lois A. Vitt, Carol Anderson, Jamie Kent, Deanna M. Lyter, Jurg K. Siegenthaler, and Jeremy Ward, Personal Finance and the Rush to Competence: Financial Literacy Education in the U.S. (study commissioned and supported by the Fannie Mae Foundation and conducted by the Institute for Socio-Financial Studies, Middleburg, Va., 2000) (www.fanniemaefoundation.org/programs/pdf/ rep_finliteracy.pdf).

11. Consumer Bankers Association, "Financial Literacy Programs: A Survey of the Banking Industry" (July 2001) (www.cbanet.org/ issues/financial_literacy/Financial_Literacy_Survey_2002.htm). 


\section{The Federal Reserve System's Role in Economic and Financial Literacy}

Recognizing the importance of educated and informed consumers to the operation of efficient markets, the Federal Reserve has been an active provider of economic literacy materials to help students and the public better understand the U.S. economy and the role of the Federal Reserve. Each of the twelve Federal Reserve Banks supports this objective through a wide variety of education partnerships, publications, learning tools, and student challenge contests.

As the importance of financial literacy has increased in recent years, the Federal Reserve has also become engaged in a broad spectrum of initiatives to further that goal. In partnership with government agencies, community groups, and other organizations, the Federal Reserve has supported programs to provide training seminars for community educators and increase awareness of abusive practices in lending and other financial services. Some Reserve Banks use their web sites as information clearinghouses, aggregating and categorizing the variety of resources that can be accessed on the Internet. Others have published manuals to help consumers understand fundamental financial management concepts and have developed electronic tools for designing personal budgets and savings plans. To contribute to the body of research on the topic, the Federal Reserve has conducted numerous studies related to consumer finances. In addition, the 2003 Federal Reserve Community Affairs Research Conference will serve as an opportunity to bring new thinking to the subject of measuring the effect of financial literacy training and determining the level of need for such education.

information intended to familiarize households with the fundamentals of saving and credit. Other programs are intended to facilitate the attainment of a specific goal, such as home ownership, savings accumulation, or debt reduction. ${ }^{12}$ Some programs are intended for a broad audience. Others are designed for a particular group, such as high school students or military personnel. For the banks surveyed by the Consumer Bankers Association, prospective homeowners were the most common focus. Another major target audience was training for youth: Three-fourths of the responding banks reported that they support financial literacy programs in public schools, through direct investment and participation in training initiatives. ${ }^{1.3}$

12. For a description of the FDIC program, see "Money Smart: An Adult Education Program" (www.fdic.gov/consumers/consumer/ moneysmart/index.html).

13. Consumer Bankers Association, "Financial Literacy Programs: A Survey of the Banking Industry."
The American Bankers Association Education Foundation offers bankers a variety of information resources to promote the importance of savings and credit management and sponsors a Personal Economics Program in which banks work with educators to teach people of all ages about banking services and financial management. ${ }^{14}$ Banks and other depository institutions also collaborate with community development organizations as a means of increasing their reach. For example, some financial institutions support the National Community Reinvestment Coalition's financial literacy initiative designed to help bring low- and moderate-income communities, minority groups, and individuals into the financial mainstream. One component of the program helps banks and local community groups develop mutually beneficial strategies for promoting financial literacy.

Employers are also common providers of financial education, and many sponsor informational and training sessions that employees can attend during the workday. For example, the Federal Reserve Board has in recent years periodically hosted sessions focusing on homebuyer orientation, budgeting and credit management, and savings for retirement and children's education. The Department of Defense, which determined that financial wellness contributes to quality of life and affects military readiness, incorporated comprehensive financial education in its basic training programs for certain personnel.

\section{FINDINGS OF EMPIRICAL STUDIES OF FINANCIAL LITERACY PROGRAMS}

While financial literacy training programs have clearly proliferated, research measuring the effectiveness of the training has not kept pace. Those studies that have been conducted use a variety of criteria for determining success, ranging from the incidence of default on home mortgages to changes in confidence levels among training participants. The body of objective research generally concludes that financial literacy training yields some benefits. Student testing and surveys of confidence in financial matters, however, produce less-definitive results.

In analyzing the efficacy of financial literacy programs, the primary challenge is defining and quantifying "success." The broad objective of all programs is to present information that will improve

14. American Bankers Association Education Foundation, "Our National Programs" (www.aba.com/Consumer+Connection/ CNC_aboutef.htm). 
consumers' ability to make decisions that are beneficial to their financial well-being. One measure of success is the achievement of a specific outcome resulting from the training, with programs that are tied to a defined goal providing the best opportunities for measuring success. Initiatives that have a significant goal-oriented educational component include programs for first-time homebuyers, savings initiatives, and workplace retirement-planning efforts.

\section{Homebuyer Counseling Programs}

Home ownership, a primary mechanism for household asset accumulation, is the cornerstone of government housing policy objectives and community development strategies. Considerable resources have been devoted to supporting consumers in purchasing a home. Prepurchase counseling has long been a way of preparing and qualifying prospective homeowners-particularly those who have low income, inadequate savings, or impaired credit histories - for the financial responsibility of a mortgage. Many affordable-housing programs include a financial literacy component, with such training generally addressing debt management, budgeting, and saving.

Within the community development arena, homebuyer counseling has been a fundamental strategy for increasing home ownership among disadvantaged households in distressed communities. As a catalyst for neighborhood stabilization, community organizations provide financial literacy training to develop "bankable" borrowers who can qualify for a mortgage and appropriately manage their debt. Neighborhood Housing Services, a subsidiary of the Neighborhood Reinvestment Corporation (NRC), was one of the first community-based affordable-housing programs to institute this practice. ${ }^{15} \mathrm{NRC}$ and its umbrella network, NeighborWorks, provided homebuyer training, both before and after purchase, to more than 71,000 individuals in fiscal year 2001 .

Maintenance of a mortgage loan in accordance with the contract is a desired outcome of many homebuyer counseling programs, and timely payments are a measure of their success. Using payment performance as a measure of success, Freddie Mac, one of the largest purchasers of mortgage loans, conducted a study of nearly 40,000 mortgages originated from

15. The Neighborhood Reinvestment Corporation was created by Congress in 1978 to revitalize older, underserved areas through community-based approaches to support redevelopment and affordable housing.
1993 through 1998 under its affordable mortgage loan program, Affordable Gold. ${ }^{16}$ Some borrowers had received prepurchase counseling, and others had not; those who had received counseling had received it from a variety of sources, including government agencies, mortgage insurers, and nonprofit groups. The objective of the study was to determine whether prepurchase home ownership counseling affected ninety-day delinquency rates and whether effectiveness varied with training format (individual counseling, group classes, home study, or telephone counseling). Borrowers receiving counseling had, on average, a 19 percent lower ninety-day delinquency rate than borrowers with "equivalent observable characteristics" not receiving counseling. Those who received individual counseling had a 34 percent lower delinquency rate than those who received no counseling, and those who received classroom and home study training had 26 percent and 21 percent lower delinquency rates respectively. Telephone counseling did not lower delinquency rates. The reduction in delinquency rates was found to be attributable to the type of counseling format, regardless of the organization providing the counseling.

\section{Savings Initiatives}

Financial literacy training is integral to many initiatives designed to increase the rate of saving among middle- and lower-income households. America Saves-a program in which communities conduct local savings campaigns - was begun by the Consumer Federation of America in May 2001. The program includes efforts to enroll residents as savers and the provision of no-fee savings accounts, motivational workshops, and one-on-one consultation. The pilot program in Cleveland, Ohio, has more than 100 organizational participants, has enrolled 1,500 "Cleveland Savers," and has involved more than 2,000 individuals in motivational workshops. An areawide survey suggests that through these efforts, some 10,000 Cleveland-area residents have been persuaded to save more effectively. ${ }^{17}$ Since the launch of the pilot program, America Saves campaigns have been initiated in Kansas City and are being organized in other cities, including Indianapolis and Charlotte.

16. Abdighani Hirad and Peter M. Zorn, "A Little Bit of Knowledge Is a Good Thing: Empirical Evidence of the Effectiveness of Pre-purchase Homeownership Counseling" (Freddie Mac, May 2001).

17. America Saves, "One-Quarter of U.S. Households Are Wealth Poor," press release, May 13, 2002 (www.americasaves.org/ back_page/savinginamerica_first.cfm). 
Money 2000, a program sponsored by the U.S. Department of Agriculture through its Cooperative Extension Service (a division of the agency's Cooperative State Research, Education, and Extension Services program) was initiated to provide information and tools to consumers seeking to improve their savings and spending patterns. Program participants reporting progress toward their financial goals increased their savings, on average, approximately $\$ 1,600$ within a twelve-month period and decreased their credit balances an average of more than $\$ 1,200 .{ }^{18}$

Other, more focused efforts support asset development among lower-income households through the use of monetary incentives. Matched-savings programs known as individual development accounts (IDAs) were designed to address the concern that many lower-income earners do not have access to employer-sponsored savings programs, such as 401(k) plans. Participants open savings accounts and specify a savings objective. Their contributions are matched by sponsoring organizations such as nonprofit organizations, corporations, government agencies, and foundations. Matching funds are forfeited if the funds are withdrawn for any reason other than to purchase a home, start a small business, or fund higher education.

To determine the effectiveness of IDAs, the Corporation for Enterprise Development initiated a pilot project involving fourteen IDA programs throughout the country, the American Dream Demonstration (ADD). Participants in the programs received an average of ten and one-half hours of financial training. An evaluation of ADD programs, participants, and savings patterns from September 1997 through June 2000 found generally favorable outcomes. ${ }^{19}$ Although IDAs have many features that can influence success rates, such as voluntary enrollment and matching funds, financial training appears to have played an important role: Average monthly net deposits increased with each additional hour of training up to twelve hours (training beyond that amount had little effect).

18. Money 2000 recently became Money 2020 and is being incorporated into the America Saves program (www.money2000.org/).

19. The Corporation for Enterprise Development is a nonprofit organization that promotes asset-building and economic opportunity strategies primarily in low-income and distressed communities. The evaluation of the ADD programs is reported in Mark Schreiner, Michael Sherraden, Margaret Clancy, Lissa Johnson, Jami Curley, Michal Grinstein-Weiss, Min Zahn, and Sondra Beverly, "Savings and Asset Accumulation in Individual Development Accounts: Downpayments on the American Dream Policy Demonstration, A National Demonstration of Individual Development Accounts" (Washington University in St. Louis, February 2001) (http://gwbweb.wustl.edu/csd Publications/ADDreport2001/index.htm).

\section{Workplace Programs}

As employers have shifted from offering employerdriven defined-benefit retirement plans to employeedirected defined-contribution plans, many individuals have of necessity assumed greater responsibility for planning for their financial needs in retirement. Many employers have instituted training seminars to help employees assess their needs and evaluate their options for the future.

A study by Fannie Mae found that employers most often initiated financial education for reasons associated with their $401(\mathrm{k})$ programs - to increase participation and contribution levels, to comply with related regulations, and to avoid potential liability for losses..$^{20}$ The study profiled programs on long-term financial and retirement planning at Weyerhaeuser Company and United Parcel Service (UPS). The Weyerhaeuser program was begun in 1984 , and the UPS program in 2000; both are strongly supported by management and are offered at regular intervals. The programs consist of one- or two-day workshops tailored to particular age groups. Employees receive extensive resource materials, including workbooks that incorporate explanations of the companies' benefits in the context of broader financial planning strategies. The Weyerhaeuser program takes a holistic approach, covering nonfinancial topics such as health and quality of life in the workshops. The UPS program augments written resource materials with a web-based service to help employees develop a personal financial action plan and computer software to provide information on such topics as budgeting, managing debt, saving, insurance, and wills.

Employee response to workplace financial education programs and the results of studies of the influence of such training on employee financial behavior have generally been favorable. One study found that employees who attended training workshops subsequently increased their participation in 401(k) plans. ${ }^{2 \perp}$ Another study drew a similar conclusion, with more than half of those participating in counseling sessions and workshops changing at least one financial behavior. ${ }^{x 2}$ In a study evaluating the effec-

20. Lois A. Vitt and others, Personal Finance and the Rush to Competence.

21. Jinhee Kim, Constance Y. Kratzer, and Irene E. Leech, "Impacts of Workplace Financial Education on Retirement Plans," in Jeanne M. Hogarth, ed., Proceedings of the 2001 Annual Conference of the Association for Financial Counseling and Planning Education, p. 28.

22. Jinhee Kim, "The Effectiveness of Individual Financial Counseling Advice," in Jeanne M. Hogarth, ed., Proceedings of the 2001 Annual Conference of the Association for Financial Counseling and Planning Education, pp. 62-69. 
tiveness of financial education offered by a chemical production company, 75 percent of employees reported deriving a sense of benefit from workplacesponsored training; they believed that they had made better financial decisions after attending the workshop and were overall more confident in making investment decisions. ${ }^{25}$ Other researchers conducted a telephone survey of a national sample of individuals aged thirty to forty-eight to examine the effects of employer-based financial education on savings, both in general and for retirement. Retirement accumulation, by nearly all measures, was found to be significantly higher for respondents whose employers offered financial education. In addition, rates of participation in 401(k) plans for both respondents and spouses were higher in the presence of employer-sponsored financial education. The study found a significant relationship between financial education and the rate of total saving; however, there was essentially no relationship between financial education and total wealth accumulation. ${ }^{24}$

Studies of workplace-sponsored financial training have also focused on benefits to employers. The study at the chemical production company, for example, found that financial wellness was positively correlated with worker productivity (as measured by supervisors' performance ratings) and worker health (as a function of absentee records). ${ }^{25}$

\section{RESULTS OF SURVEYS \\ OF GENERAL FINANCIAL TRAINING PROGRAMS}

While studies generally find a positive correlation between financial training and the achievement of specific goals, the results of surveys measuring the acquisition of more general, more comprehensive financial literacy are less clear cut. A 1995 telephone survey of a nationally representative sample of individuals aged thirty to forty-nine to measure the longterm effects of financial curricula in high schools across the country found that state-mandated financial education resulted in both increased exposure to such information and improved asset accumulation

23. E. Thomas Garman, Jinhee Kim, Constance Y. Kratzer, Bruce H. Brunson, and So-hyun Joo, "Workplace Financial Education Improves Personal Financial Wellness," Financial Counseling and Planning Journal, vol. 10 (issue 1, 1999), pp. 79-99.

24. B. Douglas Bernheim and Daniel M. Garrett, "The Effects of Financial Education in the Workplace: Evidence from a Survey of Households," Joumal of Public Economics (forthcoming).

25. E. Thomas Garman and others, "Workplace Financial Education Improves Personal Financial Wellness." when participating students reached adulthood. ${ }^{26}$ A more recent study, based on data from the 1999 Freddie Mac Consumer Credit Survey, concluded that specific and detailed knowledge of financial affairs had little effect on behaviors and outcomes, and that confidence and a broad understanding were more important predictors of successful financial outcomes. ${ }^{27}$ The study also found that consumers appear to benefit from practical and applied learning: The major source of learning for all groups was a difficult financial experience. The researchers concluded that teaching financial literacy in the abstract appears to be ineffective and that providing consumers with ready access to information on an ongoing basis may better help households having minor financial difficulties avoid exacerbating their situation through unproductive behaviors.

Other surveys have sought to measure the shortterm effects of financial training targeted at secondary school students. One such survey was a 1997-98 evaluation by the National Endowment for Financial Education (NEFE) of its High School Financial Planning Program. ${ }^{2 x}$ The survey compared students' responses to questions about their financial behaviors, financial knowledge, and confidence levels in managing financial matters before and after participating in the program. Nearly 30 percent of the students reported that they started saving after participating in the training, and 15 percent indicated that they began saving more. In addition, 37 percent of the students stated that they had better skills for tracking spending, 47 percent believed that they were more knowledgeable about the cost of credit, and 38 percent indicated that they were both better informed about investments and more confident about managing money after participating in the program.

While the NEFE survey results indicate that general financial literacy training can be useful for students, at least for a short period after the training,

26. B. Douglas Bernheim, Daniel M. Garrett, and Dean Maki, "Education and Saving: The Long-Term Effects of High School Financial Curriculum Mandates," NBER working paper w6085 (National Bureau of Economic Research, July 1997).

27. The study was based on data for more than 12,000 individuals across the country aged twenty to forty with household incomes of less than $\$ 75,000$. Study results are discussed in Donald Bradley, Abdi Hirad, Vanessa Gail Perry, and Peter Zorn, "Is Experience the Best Teacher? The Relationship between Financial Knowledge, Financial Behavior, and Financial Outcomes," paper submitted to the Rodney L. White Center for Financial Research, University of Pennsylvania, Workshop on Household Financial Decision Making, March 2001 .

28. Laurie Boyce and Sharon M. Danes, "Evaluation of the NEFE High School Financial Planning Program, 1997-1998" (report of a study sponsored by the National Endowment for Financial Education) (www.nefe.org/pages/educational.html). 
scores on a test administered to high school seniors by the Jump\$tart Coalition, a nonprofit financial education advocacy group, present a less clear view of the relationship between training, knowledge, and confidence. Over a period when attention to public school training in personal finance was increasing, average scores on a multiple-choice test of seniors' knowledge of the basics of personal finance were declining-from 57 percent in 1999 to 52 percent in 2000 to 50 percent in $2002 .{ }^{29}$ In fact, students in the 2002 study who had received an entire semester of training scored a bit worse on the test than those who had not, and students in states having a statewide training requirement scored worse than those in states having no requirement. Notably, in the 2002 survey, students who had participated in an interactive stock market game as part of their training scored better on the survey ( 52 percent) than did students overall and better than those who had received other types of training. Despite the low average score, 65 percent of the students tested in 2002 indicated that they felt "somewhat sure" or "very sure" of their ability to handle their finances.

\section{INFLUENCE 'OF BEHAVTOR TRATTS AND LEARNING PREFERENCES}

Although research shows that the acquisition of additional information can result in improved behavior in financial matters, studies also make clear that increased information does not automatically result in such improvement. While the overarching objective of financial literacy training is to impart knowledge that will, ultimately, improve financial behaviors, the assumption that the presence of more information will lead to improved behavior is faulty. The conundrum of why, in the presence of reliable and credible information, households do not always act in their best financial interest-as the efficientmarkets model contends they should - is explored by the discipline of behavioral economics. Research in behavioral economics can contribute to the development of policies and programs that motivate positive change.

In examining the disconnect between the efficientmarkets model and the "nonrational" behaviors in which consumers engage, a study funded by the National Bureau of Economic Research (NBER) pos-

29. The results of the 2002 Personal Financial Literacy Survey are available at www.jumpstart.org/download.cfm. Also see "From Bad to Worse: Financial Literacy Drops Further among 12th Graders," Jump\$tart press release, April 23, 2002. its that the risk-either real or perceived-associated with experimenting with something new will cause an individual to remain in a situation that is not optimal. ${ }^{30}$ The study's authors also note several economically self destructive aspects of behavior, such as overconfidence (investing in the absence of complete information), overreaction (exaggerated response to new information), selflessness (giving to charity despite one's financial situation), and loss aversion (delayed entry into or exit from a financial situation inconsistent with one's financial best interest). Recognition of these behavioral traits can help financial literacy trainers understand households' priorities and create financial training programs that take these traits into consideration.

With respect to savings, the NBER authors suggest that consumers' lack of self-discipline necessitates strategies and policies that force savings, such as automatic enrollment in 401(k) investment plans and tax benefits to motivate contributions to individual retirement accounts. Other mechanisms consumers commonly use that can be characterized as forced savings are the overwithholding of income taxes to ensure a refund and the accumulation of home equity through mortgage payments and property appreciation.

In one study of a savings program that capitalizes on the propensity of households to engage in passive savings, researchers examined the Save More Tomorrow (SMT) program, through which employees commit, in advance, a portion of their future salary increases toward their (employee-directed) definedcontribution retirement plan. ${ }^{31}$ Program participants are offered ongoing counseling by an investment adviser. Although the study was not based on random assignment, as participants self-selected into the program, the findings are compelling: Savings rates of participants tripled in twenty-eight months; 78 percent of eligible employees elected to participate; and the vast majority of participants remained in the program through two or three pay increases ( 98 percent and 80 percent respectively).

The manner in which information is presented can also influence the effectiveness of financial literacy programs. A recent Federal Reserve study based on the November and December 2001 Surveys of Consumers

30. Sendhil Mullainathan and Richard H. Thaler, "Behavioral Economics," NBER working paper w7948 (National Bureau of Economic Research, October 2000).

31. Richard H. Thaler and Shlomo Benartzi, "Save More Tomorrow: Using Behavioral Economics to Increase Employee Saving" (working paper prepared at the University of California at Los Angeles, August 2001). (For information on the Save More Tomorrow program, see http:/gsbwww.uchicago.edu/news/capideas/summer02/ savemoretomorrow.html). 
2. Proportion of consumers who have various financial products and engage in various financial behaviors, by consumer money management style Percent

\begin{tabular}{|c|c|c|c|c|c|}
\hline \multirow{2}{*}{ Product or behavior } & \multicolumn{5}{|c|}{ Money management style } \\
\hline & All consumers & Inactive/Unengaged & Inactive/Engaged & Active/Unengaged & Active/Engaged \\
\hline \multicolumn{6}{|l|}{ Financial product } \\
\hline Checking account & 89 & 74 & 100 & 92 & 100 \\
\hline Savings account ..... & 80 & 61 & 93 & 85 & 94 \\
\hline Certificate of deposit & 30 & 14 & 38 & 20 & 52 \\
\hline \multicolumn{6}{|l|}{ Investment products } \\
\hline Any investment account & 52 & 17 & 84 & 31 & 93 \\
\hline Mutual fund $. . . \ldots . . .$. & 46 & 15 & 69 & 28 & 84 \\
\hline Public stock. . & 24 & 7 & 43 & 11 & 43 \\
\hline Bonds $\ldots \ldots \ldots . . .$. & 6 & 1 & 7 & 4 & 12 \\
\hline \multicolumn{6}{|l|}{ Retirement products } \\
\hline Company pension plan or $401(\mathrm{k})$ plan & 45 & 19 & 72 & 27 & 74 \\
\hline $\begin{array}{l}\text { IRA or Keogh } \ldots \ldots \ldots \ldots \ldots \ldots \ldots \ldots \\
\text { Credit products }\end{array}$ & 43 & 16 & 70 & 21 & 76 \\
\hline \multicolumn{6}{|l|}{ Credit products } \\
\hline Mortgage & 72 & 53 & 87 & 70 & 91 \\
\hline $\begin{array}{l}\text { Refinanced mortgage or loan for home } \\
\text { improvements }\end{array}$ & 35 & 16 & 51 & 23 & 57 \\
\hline \multirow{2}{*}{$\begin{array}{l}\text { At least one financial product ........ } \\
\text { Memo: Average number of financial } \\
\text { products owned ..................... }\end{array}$} & 97 & 92 & 100 & 100 & 100 \\
\hline & 7 & 4 & 9 & 5 & 10 \\
\hline \multicolumn{6}{|l|}{ Financial behavion } \\
\hline \multicolumn{6}{|l|}{ Cash-flow management } \\
\hline Pay all bills on time $\ldots \ldots \ldots$ & 88 & 75 & 90 & 96 & 98 \\
\hline Have a recordkeeping system & 65 & 41 & 51 & 83 & 89 \\
\hline Balance checkbook monthly & 67 & 49 & 64 & 82 & 82 \\
\hline Track expenses ................ & 59 & 41 & 32 & 86 & 76 \\
\hline Use a spending plan or budget ..... & 46 & 34 & 14 & 71 & 59 \\
\hline \multicolumn{6}{|l|}{ Savings } \\
\hline Have an emergency fund $\ldots \ldots \ldots \ldots \ldots \ldots$ & 63 & 30 & 60 & 81 & 93 \\
\hline Save or invest money out of each paycheck & 49 & 20 & 40 & 64 & 78 \\
\hline $\begin{array}{l}\text { Save for long-term goals such as education, } \\
\text { car, home, or vacation }\end{array}$ & 39 & 14 & 16 & 59 & 65 \\
\hline Plan and set goals for financial future ..... & 36 & 20 & 10 & 57 & 54 \\
\hline \multicolumn{6}{|l|}{$\begin{array}{l}\text { Investment } \\
\text { Have money in more than one type }\end{array}$} \\
\hline of investment .................... & 53 & 16 & 74 & 46 & 93 \\
\hline Calculated net worth in past two years & 40 & 14 & 33 & 47 & 68 \\
\hline \multicolumn{6}{|l|}{$\begin{array}{l}\text { Participate in employer's } 401(\mathrm{k}) \\
\text { retirement plan }\end{array}$} \\
\hline \multicolumn{6}{|l|}{$\begin{array}{l}\text { Put money into other retirement plan, } \\
\text { such as an IRA }\end{array}$} \\
\hline such as an IRA $\ldots \ldots \ldots \ldots \ldots$. & 22 & 4 & 16 & 22 & 47 \\
\hline $\begin{array}{l}\text { Credit } \\
\quad \text { Review credit report } \ldots \ldots \ldots \ldots \ldots \ldots \ldots \ldots \ldots \ldots \ldots \ldots\end{array}$ & 58 & \\
\hline Pay credit card balances in full each month ..... & 49 & 21 & 53 & 54 & 76 \\
\hline Compare offers before applying for a credit card & 35 & 21 & 34 & 44 & 47 \\
\hline \multicolumn{6}{|l|}{ Other } \\
\hline Do own taxes $\quad \ldots \ldots \ldots \ldots \ldots \ldots \ldots \ldots \ldots$ & 40 & 31 & 31 & 47 & 51 \\
\hline Read about personal money management & 20 & 5 & 9 & 23 & 40 \\
\hline At least one financial behavior $\ldots \ldots \ldots \ldots \ldots \ldots$ & 100 & 100 & 100 & 100 & 100 \\
\hline Memo: Average number of behaviors engaged in & 9 & 5 & 7 & 12 & 13 \\
\hline
\end{tabular}

looked at the perceived effectiveness of different means of information delivery and numerous other aspects of money management. ${ }^{32}$ The study identified money management styles and factors associated with those styles, information resources used by

32. The Survey of Consumers is a monthly telephone survey of a sample of U.S. households conducted by the University of Michigan Survey Research Center. Information on the Federal Reserve study is from Jeanne M. Hogarth, Marianne A. Hilgert, and Jane Schuchardt, "Money Managers-The Good, the Bad, and the Lost," paper presented at the Association for Financial Counseling and Planning Education Conference, Scottsdale, Arizona, November 2002. households, and perceptions about effective information sources. It also provided insight into household cash-flow management, saving and investment, and retirement planning.

Survey respondents were classified in terms of the number of financial products they used or owned (from a list of thirteen) and the number of financial behaviors they exhibited (from a list of eighteen). Respondents who ranked above the median in both number of products (labeled "engaged" consumers) and number of behaviors (labeled "active" consum- 
3. Proportion of consumers who obtained financial information from various sources, by consumer money management style Percent

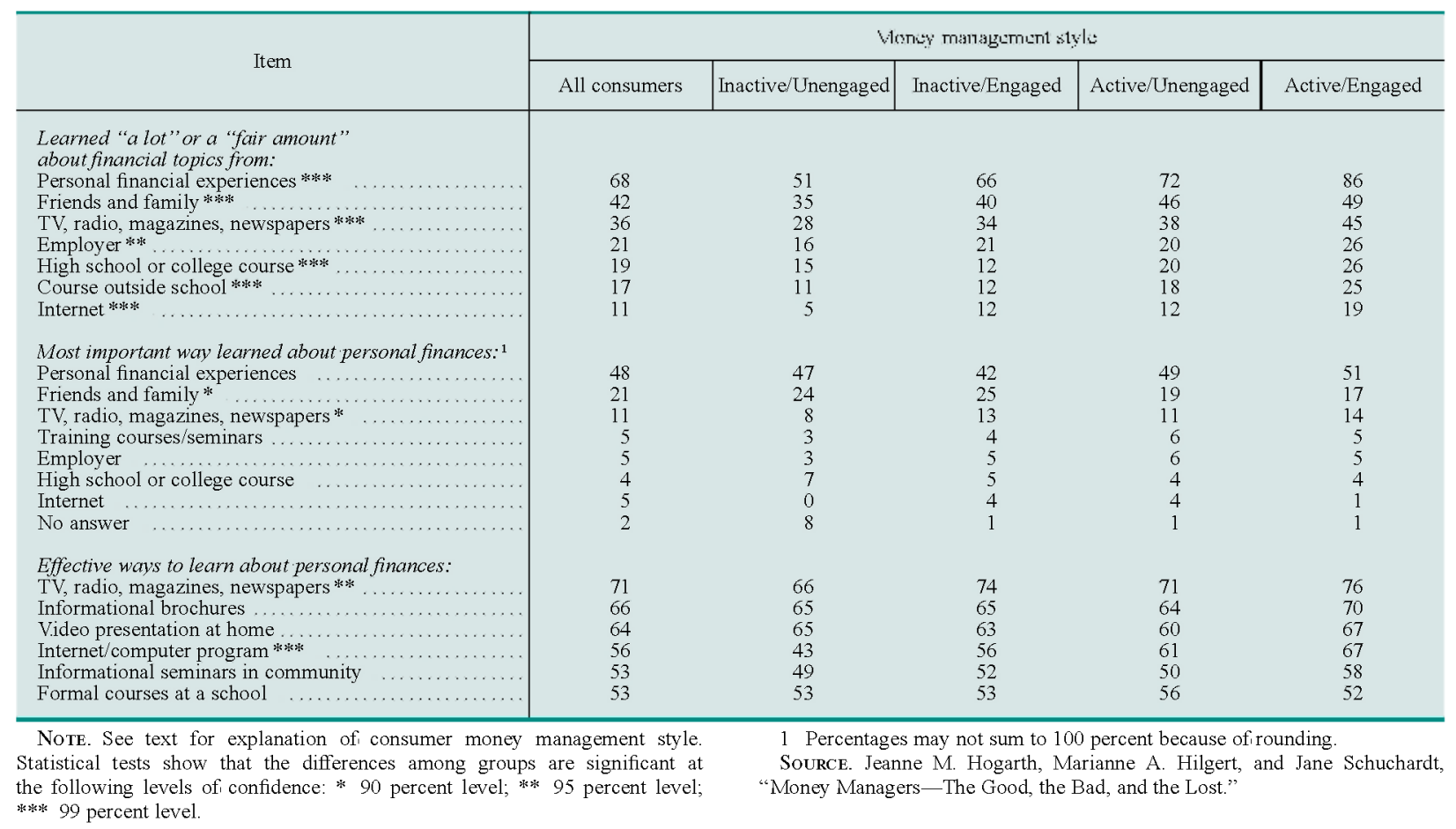

ers) owned, on average, ten of the thirteen financial products and exhibited thirteen of the eighteen financial behaviors, while the average respondent below the medians (inactive/unengaged consumers) owned only four of the products and exhibited only five of the behaviors (table 2).

To measure level of financial knowledge, the survey asked a series of true-false questions concerning savings, credit, and other general financial management matters. Overall, respondents answered 67 percent of the questions correctly; active/engaged consumers answered 76 percent correctly, and inactive/ unengaged consumers answered 59 percent correctly. Test score, income, and level of education were the only variables found to have a statistically significant relationship to money management style: Respondents with higher test scores, greater income, and a higher level of education were more likely to be active/engaged and less likely to be inactive/ unengaged than other respondents - a finding supporting the value of financial literacy education.

Most commonly cited as the most important source of information about personal finances was personal experience; smaller proportions of respondents cited friends and family and mass media (TV, radio, magazines, and newspapers) as their most important source (table 3 ). Most commonly cited as effective ways to learn about personal finances were mass media, information brochures, and video presentations at home. The Internet, seminars, and classroom courses ranked somewhat lower, with active respondents generally more likely than inactive respondents to consider these effective ways to learn about financial management. Those sources generally considered most effective can be classified as individually focused and available "on demand"-that is, consumers appear to want information at a time of their choosing, not on someone else's schedule. Those who did tend to see a group environment as an effective venue for learning were more likely to be active, engaged consumers.

Data of this sort promise to be helpful in the design of financial education programs and the development of strategies for reaching various target groups most effectively. For example, by cross-referencing socioeconomic data collected in the survey (not reported here) with the data on effective sources of information, the design and delivery of programs can be tailored to be more responsive to the preferences of learners.

\section{POLICY IMPLICATIONS AND PROGRAM CHALLENGES}

Overall, evidence concerning the benefits of financial training is consistent with conventional wisdom- 
education can result in more-informed consumers who make better financial decisions. When it comes to specifics, however, many challenges remain in identifying the most effective and most efficient means of providing relevant information to educate consumers at appropriate points in their financial life cycle. Demonstration of program effectiveness is critical to maintaining the current level of interest in and resources devoted to financial literacy education. Certainly, the matter has received the attention of policymakers, with members of the Federal Reserve Board addressing the topic on numerous occasions and Congress holding two days of hearings on the subject in February 2002.33 In addition, the Department of the Treasury has established an Office of Financial Education dedicated to providing resources and contributing to policy on financial literacy. ${ }^{34}$ And the No Child Left Behind Act of 2001 commits federal funding for innovative assistance programs at the local level, including "activities to promote consumer, economic and personal finance education, such as disseminating information on and encouraging use of the best practices for teaching the basic principles of economics and promoting the concept of achieving financial literacy. ..."

The challenges for policymakers and educators in designing and delivering financial literacy education to meet the needs of all groups within the population are many. The elements that must be considered can be defined broadly in a set of questions:

- Who is the targeted audience and what are the group's information needs?

- What does the audience need to know to understand personal financial circumstances, identify future goals, and implement behaviors consistent with attainment of those goals?

- When is the appropriate time to expose individuals to both general and specific information about financial issues and options?

33. See, for example, "Financial Literacy," testimony by Chairman Alan Greenspan before the U.S. Senate Committee on Banking, Housing, and Urban Affairs, February 5, 2002; "Reflections on Financial Literacy," speech by Vice Chairman Roger W. Ferguson, Jr., before the National Council on Economic Education, May 13, 2002; and "Financial Literacy," speech by Governor Edward M. Gramlich at the Financial Literacy Teacher Training Workshop, University of Illinois at Chicago, May 2, 2002.

Also see "Hearings on the State of Financial Literacy and Education in America," U.S. Senate Committee on Banking, Housing, and Urban Affairs, February 5-6, 2002 (www.senate.gov/\%7Ebanking/ $02 \_02 \mathrm{hrg} / 020502 /$ index.htm and www.senate.gov/\%7Ebanking/ $02 \_02 \mathrm{hrg} / 020602 /$ index.htm).

34. U.S. Department of the Treasury, "Treasury Department Announces Office of Financial Education-New Deputy Assistant Secretary for Financial Education in Place," press release, May 7, 2002 (www.treas.gov/press/releases/po3079.htm)
- Where should financial literacy education be provided to reach the broadest audience?

- How can financial literacy education be effectively delivered, both at specific points in time and over time, to assist houscholds in adjusting their financial plan to suit their circumstances?

- How can the effectiveness and impact of financial literacy programs be measured?

The task, which may appear simple when reduced to a series of bullet items, becomes complex when these variables are considered simultaneously or the multiple implications of just one variable are evaluated fully. For example, in considering where to introduce financial management topics to youth, the public school system may seem a logical place. However, issues of funding and teaching priorities complicate the use of this venue. Even when states mandate personal finance education, the question remains of how to incorporate training into existing student curricula, as specific requirements related to academic performance and the desire to offer worthwhile but competing electives, such as foreign languages and music, may leave little room for a separate course. Similarly, while research identifies the workplace as an effective venue for extending financial literacy to adults, the existence of workplace programs is dependent on management philosophy and corporate culture, and as a result, programs may not be available to large segments of the population.

The challenge of providing financial training to adults is particularly vexing in light of the wide variety of information needs arising from differences in prior experience, language and cultural background, current financial situation, and time availability, given work and family commitments. The wide variation in needs also poses challenges in the development and delivery of relevant information. Most classroom-style programs take a "one size fits all" approach, in a well-intended effort to provide as much information as possible in a limited amount of time. Such training may not be enough for some participants and too much for others. Many education providers use the Internet to offer resources and referrals, allowing consumers to choose, among a range of topics, the information that best suits their needs. But this approach has limited utility for consumers who cannot access a computer, have limited language or reading skills, or need a more personalized training experience.

In an ideal world, financial educators would analyze each individual's needs and provide customized training based on that assessment. But such one-onone interaction is time- and resource-intensive. Thus, 
educators are seeking other ways to analyze consumer needs more effectively and deliver pertinent information more efficiently. One approach might parallel in some ways the use of a credit-scoring model in loan underwriting, which has enabled lenders to quickly and effectively construct an individual risk profile. A similar approach might be taken in determining a consumer's financial literacy profile, with a database on an individual's or group's financial status, behavior, and learning preferences used to identify an individual's information and educational needs. Knowledge of those needs, coupled with an assessment of the individual's motivation and confidence, could assist in providing relevant financial information at the appropriate time.

The development of consistent standards for measuring results, too, could increase the success of financial literacy programs. Practitioners who can demonstrate the effectiveness of their programs can contribute significantly to the identification of "best practices" and the setting of policies that may lead to consumers who are better equipped to survive and, more important, thrive in our vibrant, diverse, complex financial marketplace. 